\title{
Effects of moderate-intensity continuous training therapy on claudication symptoms and carotid intima-media thickness in patients after endovascular and classical bypass treatment (a pilot study)
}

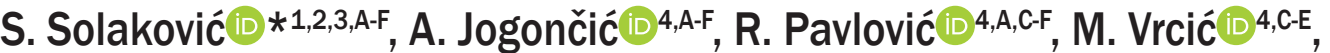 \\ N. Čović $\mathbb{D}^{4, A, C-E}$, E. Solaković ${ }^{2}$ 2,B-F, I. T. Skrypchenko ${ }^{5, A, C-F}$, D. Čaušević ${ }^{4, C-E}$, \\ O. Ye. Dorofieieva ${ }^{6, C-F}$, K. S. Yarymbash ${ }^{6, C-E}$
}

${ }^{1}$ Cardiovascular Surgery Clinic and Vascular Surgery Department, Clinical Center of the University in Sarajevo, BIH, ${ }^{2}$ Special Hospital dr. Solakovic, BIH, ${ }^{3}$ The International University of Gorazde (IUG), BIH, ${ }^{4}$ University of Sarajevo, BIH, ${ }^{5}$ Dnipropetrovsk State University of Internal Affairs, Dnipro, Ukraine, ${ }^{6}$ Bogomolets National Medical University, Kyiv, Ukraine

A - research concept and design; B - collection and/or assembly of data; C - data analysis and interpretation; D - writing the article; $\mathrm{E}$ - critical revision of the article; $\mathrm{F}$ - final approval of the article

Research on moderate-intensity continuous training (MICT) is closely connected with primary and secondary cardiovascular protection but also can be associated with primary bypass patency and outcome of endovascular treatment for critical iliac stenosis TASC II A and B. After specific surgical or non-surgical treatment, iliac bypass or endovascular revascularization patency still depends on an individual and is still in the eye of scientific research modalities. Carotid intima-media thickness (CIMT) is an efficient surrogate parameter in detection and prediction of cerebrovascular events and potential marker of generalized atherosclerosis with prognosis of peripheral arterial disease related to prognosis of atherosclerotic coronary hemodynamic pathology.

Materials and methods. A total of 139 patients were observed during 4 years of MICT. Ultrasonography of the distal part of the common carotid artery (CCA) was performed to measure CIMT before and after revascularization procedure. The bypass patency and walking distance was also studied.

Results. In the total population, no difference in changes of CIMT from baseline was observed between the standard exercise group and controls in 4 years. However, there was a significant correlation between the effect of exercise training and CIMT within 4 years. CIMT was not significantly reduced in the exercise group compared with control non-diabetic patients.

Conclusions. Exercise training in both groups did not significantly change carotid intima-media thickness in the four years following endovascular procedure and Dacron bypass revascularization, but significant beneficial effect of moderate-intensity continuous training on bypass patency was observed in patients with mild or without claudication symptoms as well as on subjective and objective health status.
Key words: endurance training carotid intimamedia thickness, critical iliac stenosis, bypass, endovascular treatment patency.

\section{Zaporozhye} medical journal 2020; 22 (6), 775-783

*E-mail: sid.solakovic@gmail. com

Ключові слова: тренування на витривалість, товщина інтимамедіа сонної артерії, прохіаність при шунтуванні кмубового стенозу та ендоваскулярному мікуванні.

Запорізький медичний журнал. 2020. T. 22, № 6(123) C. $775-783$

Матеріали та методи. Протягом 4 років дослідили 139 пацієнтів під час тривалих тренувань помірної інтенсивності. Виконали ультрасонограффію дальньої частини загальної сонної артерії для вимірювання товщини інтима-медіа сонної артерії до та після реваскуляризації. Визначили прохідність шунта та дистанцію безбольової ходьби.

Результати. У всіх осіб, яких дослідили, не спостерігали відмінності за зміною товщини інтима-медіа сонної артерії між стандартною та контрольною групами протягом 4 років. Однак виявили значущий взаємозв'язок між дією тренувань і товщиною інтима-медіа сонної артерії протягом 4 років. Показники товщини інтима-медіа сонної артерії несуттєво зменшилися в базовій групі порівняно з контрольною (в пацієнтів без діабету).

Висновки. Протягом 4 років після ендоваскулярної процедури та реваскуляризації дакроновим протезом тренування, що відбувалися в обох групах, несуттєво змінили розвиток показника товщини інтима-медіа сонної артерії, але спостерігали значущу позитивну дію тривалих тренувань помірної інтенсивності на прохідність шунта з незначними симптомами мікроциркуляторних порушень або їхньою відсутністю в суб'єктивному чи об’єктивному статусі пацієнта. 
Ключевые слова: тренировка на выносливость, толщина интима-медиа сонной артерии, прохоАимость при шунтировании ПОАВЗАОшнОГО стеноза и энАоваскулярном мечении.

Запорожский медицинский журнал 2020. T. 22, № 6(123). C. $775-783$

\title{
Аействие продолжительных тренировок умеренной интенсивности на микроциркуляторные нарушения и толщину интима-медиа сонной артерии у пациентов после эндоваскулярного и классического шунтирования
}

\author{
С. Солакович, А. Йогончич, Р. Павлович, М. Врчич, Н. Чович, Э. Солакович, И. Т. Скрипченко, А. Чаушевич, \\ Е. Е. Аорофеева, К. С. Ярымбаш
}

Научное исследование продолжительных тренировок умеренной интенсивности коррелирует с первичной и вторичной сердечно-сосудистой терапией, но и связано с исходом первичного обходного шунтирования и лечения эндоваскулярного подвздошного стеноза TASC II A и В. После специфического хирургического и нехирургического лечения результаты шунтирования или эндоваскулярной подвздошной реваскуляризации все еще зависят от пациента, и данные показатели актуальны для медицинских исследований. Толщина интима-медиа сонной артерии - эфффективный замещающий параметр в определении и предупреждении инсульта, а также потенциальный маркер рассеянного атеросклероза с прогнозом поражения периферических артерий в связи с прогнозом коронарной атеросклеротической гемодинамической патологии.

Материалы и методы. На протяжении 4 лет исследовали 139 пациентов во время длительных тренировок умеренной интенсивности. Проведена ультрасонография дальней части общей сонной артерии для измерения толщины интима медиа сонной артерии до и после реваскуляризации. Также определили проходимость шунта и дистанцию безболевой ходьбы.

Результаты. У всех обследованных не наблюдали отличия в изменении толщины интима-медиа сонной артерии между стандартной и контрольной группами на протяжении 4 лет. Однако отмечена значительная взаимосвязь между действием тренировок и толщиной интима-медиа сонной артерии на протяжении 4 лет. Показатели толщины интима медиа сонной артерии незначительно уменьшились в базовой группе по сравнению с контрольной (у пациентов без диабета).

Выводы. На протяжении 4 лет после эндоваскулярной процедуры и реваскуляризации дакроновым протезом тренировки, проводимые в обеих группах, незначительно изменили развитие показателя толщины интима-медиа сонной артерии, но наблюдали значительное позитивное действие продолжительных тренировок умеренной интенсивности на проходимость шунта с незначительными симптомами микроциркуляторных нарушений или их отсутствием в субъективном или объективном статусе пациента.

Although clinical benefits of physical activity, cardio-protection, neovascularization as well as a compensatory increase in collateralization hemodynamic have been scientifically proven, the association between an optimal intensity and supercompensation in an adequate physical activity after surgical or endovascular treatment of iliac segment remains unexplained. Critical atherosclerosis of iliac segment of over $75 \%$ can cause hemodynamic obstruction and thus decreased leg blood flow, which is manifested as intermittent claudication or pain at rest and requires emergent primary endovascular and/or possible secondary surgical intervention $[1,2]$. A lack of adequate synergetic implementation of postoperative vascular therapy and physical activity, as a crucial factor, is one of the predictors of endothelial dysfunction progression. Generally, what happens is that aggravated atherosclerosis significantly increases the risk of hemodynamic multi-functional disorders of various vessels including large arteries of the lower extremities, as well as primary graft passage after endovascular intervention [1,2].

Venous, Dacron or polytetrafluoroethylene (PTFE) bypass is in most cases the only key and standard invasive response to surgical revascularization of large artery distal parties, which are in ischemic progression in a patient. It is often accompanied by clinical symptomatic picture, various comorbidity, hemodynamic damages of different levels and stages, as well as by a need for postoperative rehabilitation treatment itself. Alongside endovascular procedure of critical iliac segment stenosis (TASC II A and B), the indication for classic surgical intervention is less feasible procedure which is still in the phase of scientific research on primary bypass patency and a physical activity support of adequate intensity. That is especially important in case of iliac segment ischemia and on the level of infra-popliteal segment stenosis [3,4]. Peripheral artery disease is often in correlation with coronary atherosclerosis and in combination with claudication, angina pectoris and state after myocardial infarction with low left ventricular ejection fraction. Combined symptomatology of cardiovascular diseases can represent a serious problem of disability progression and the quality of life deterioration. Because of the heart comorbidities, what is often present is the loss of the possibility to conduct an adequate physical activity programs. That physical activity would be greatly beneficial to surgically treated patients with bypass and untreated patients who suffer from peripheral artery disease with significant hemodynamic stenosis or occlusion [4-6].

In addition to risk factors (chronic nicotine intoxication and endangered nutritive imbalance of protein, fats and carbohydrates), the most common lack of physical activity is in direct correlation with cardiovascular diseases and incidents such as myocardial infarction, stroke and peripheral artery disease. Statistically significant associations with hemodynamic disturbances have been recorded in large arteries of the lower extremities which were represented as symptomatology of claudication as predictive clinical picture of type 2 diabetes mellitus occurrence. A great success can be achieved in atherosclerosis prevention through balancing the proportion of serum lipid levels (HDL-LDL) as well as by maintaining the physiological function of large blood vessels via the reduction in hemodynamic effects of systolic and diastolic blood pressure, combined with health benefits of participation in appropriate physical activity alongside adequate nutritional status and elimination or decrease of risk factors. A number of studies have shown health-promoting effect of high intensity interval training (HIIT) with load of over $90 \%$ as well as moderate intensity continuous training (MICT) with load of 50-70 \% in patient with cardiovascular pathology of different etiology [6-9]. Selective use of different interval methods alone or in synergy of combinations with continuous training, individualized for patients, showed 
the improvements in maximal oxygen uptake ( $\left.\mathrm{VO}_{2} \mathrm{max}\right)$, glycosylated hemoglobin $\mathrm{A} 1 \mathrm{c}(\mathrm{HbA} 1 \mathrm{C})$, insulin resistance $(\mathrm{IR})$, fat oxidation, body mass index (BMI) as well as in a wide range of cardiovascular risks in addition to cardiovascular system responses and hormonal profiles in symptomatic and asymptomatic cardiovascular patients. Pooled data analysis of various studies over the past 4 decades and outcomes of vascular therapy for claudication in Fontaine stage II peripheral arterial disease has shown the best treatment results if intermittent walking to near-maximal pain, duration longer than 30 minutes, 3 times a week for more than 6 months. Thus, patients demonstrated improvements in initial and absolute claudication distance that was assessed with a treadmill test at a constant-load of 0.82-1.06 Watt/kg. The average increase was $+150 \%$ and $+200 \%$ in initial and absolute claudication distance, respectively. However, the benefit of exercise training scored moderately (6-32\%). Nevertheless, because of frequent heart disease and its related comorbidities as well as previous cardiovascular events, the benefits of the training process were limited in certain instances, therefore more substantive results have been obtained after surgical and conservative-medical treatment. Meanwhile, the positive impact of physical activity on hemodynamics after the application of aorto-iliac synthetic vascular grafts or femoro-popliteal bypass (endovascular treatment, venous or synthetic bypass) has been recorded. In addition, the quality of life and performance have improved, there was significant symptomatic benefit for patients with primary disease and for a distal revascularized arterial segment, as well as the transition of clinical symptomatic period of peripheral artery disease into asymptomatic one [7-13].

Metabolic equivalent of task (MET) is a basic indicator of the resting metabolism reflecting metabolic rate for measuring energy expenditure or assessing amount and intensity of physical activity during exercise. Moderate-intensity physical activity is measured by maximum heart rate and physical strain intensity of 50-70\%. That usually corresponds to aerobic glycolysis and metabolism of fatty acids within 4.0-5.9 MET units.

\section{Aim}

The primary objective of the study included determining the postoperative outcomes and Dacron graft patency, feasibility of self-expendable stent and venous autologous conduit after aorto-iliac Dacron graft surgical and endovascular procedure (iliac segment stenting using self-expendable stent) and femoro-popliteal bypass with autologous venous graft in continuous aerobic and anaerobic training (bicycle / treadmill / upper body exercises of moderate and 4.0-5.9 MET subjective intensity) with interval sessions of over $70 \%$ (MET 5.9) and 1-3 minutes' duration.

The secondary objective was to assess whether the effects of MICT improve the comorbid states, reducing risk factors and stimulating the overall treatment success as well as to evaluate the carotid intima-media thickness (CIMT).

\section{Materials and methods}

The study was conducted in the Clinical Centre of the University in Sarajevo, Vascular Surgery Clinic and on the Faculty of Sports and Physical Education in Sarajevo in the period of four years (March 2013 - March 2017). The study included 139 patients with different risk factors (type 1 and type 2 diabetes mellitus, hypertension, hyperlipidemia, dyslipidemia) after iliac segment endovascular revascularization procedure by classic surgical approach and exercise-based addressing risk factors.

The patients were carefully selected. It is important to note that the study did not involve patients with recent myocardial infarction (over the past 12 months), with an ejection fraction of $50 \%$ or higher, coagulopathies, malignant processes, strokes, any type of amputation surgery.

Types of surgical and endovascular interventions:

- endovascular intervention in the iliac segment (iliac self-expendable stent/PTA (percutaneous transluminal angioplasty) TASC II A and B;

- PTA in the common iliac artery (TASC II A);

- aorto-iliac bypass (Dacron) 6-9mm;

- ilio-femoral bypass (Dacron) 6-9mm;

- aorto-femoral bypass (Dacron) 6-9mm;

- femoro-popliteal reversed bypass with autologous contralateral or ipsilateral great saphenous vein (GSV) graft as a venous conduit.

Ethical implications. Bearing in mind the postoperative patient follow-up, no ethical principles have been violated or additionally amended in this study.

Procedures (modified training protocol). Vascular rehabilitation program included the patients with aortoiliac and femoro-popliteal revascularization (synthetic and venous graft) with no clinical picture of critical ischemia. A training session involved walking on a treadmill with load of 60-70\% of heart rate, as well as upper body exercises with interval short loads of $80-85 \%$ of heart rate for $1-3$ minutes per every 10 minutes of the session (repetition method / resistance training). Over a period of four years, all participants exercised 2-4 times per week with each session. Patients who underwent treadmill test were examined according to the Bruce protocol for the assessment of MET before and after the training in order to select suitable candidates for the study. Bypass or endovascular procedure patency was measured by a clinical picture based on primary outcomes, claudication symptomatology or its symptoms absence. Linear array ultrasound probe $(7.5 \mathrm{MHz})$ was used to assess synthetic or venous graft and measure progression or regression in CIMT.

Statistical analysis. Descriptive statistics were performed on all variables. One-way analysis of variance (ANOVA) was used to compare the means of continuous variables between the groups. Fischer's exact test were used to compare qualitative data. AP value $<0.05$ was considered statistically significant. Statistical analysis was performed using MedCalc software version 15.8 (MedCalc ${ }^{\odot}$ Software bvba, Ostend, Belgium) and MS Office package 2016.

\section{Results}

In total, 139 patients were followed-up within 4 years. There were 78 males and 64 females, $P=0.174$. Based on sex and age, male subjects were older, but without any significant difference (Fig. 1). Reconstruction with a Dacron vascular prosthesis as a proper choice of operative procedure was performed on 94 patients. During the four-year follow-up period, the average self-reported distance after which the participants 


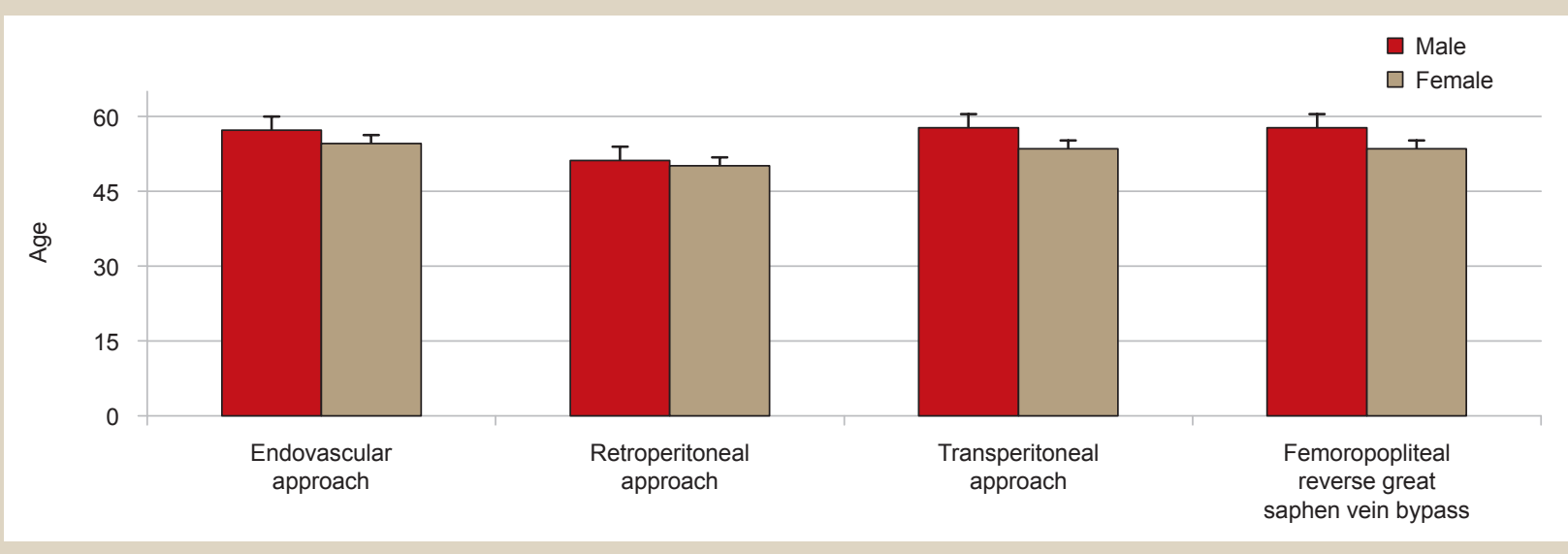

Fig. 1. Age difference between patients with retroperitoneal, transperitoneal and femoro-politeal endovascular approach using reversed great saphenous vein graft.

Table 1. Impact of training on claudication symptoms

\begin{tabular}{|c|c|c|c|c|}
\hline Surgical reconstruction patency & 1 year & 2 years & 3 years & 4 years \\
\hline Patients with Dacron graft, $\mathrm{n}$ & 94 & 92 & 92 & 91 \\
\hline Symptoms of claudication (walking distance on the treadmill test >200 m) & $12(12.8 \%)$ & $14(15.2 \%)$ & $17(18.5 \%)$ & $21(23.1 \%)$ \\
\hline Symptoms of claudication (walking distance on the treadmill test <200 m) & $14(14.9 \%)$ & 0 & $2(2.2 \%)$ & $2(2.2 \%)$ \\
\hline Type 1 diabetes mellitus & 3 & 3 & 3 & 3 \\
\hline Type 2 diabetes mellitus & 5 & 5 & 5 & 5 \\
\hline Patients with GSV conduit, $n$ & 14 & 13 & 12 & 12 \\
\hline Symptoms of claudication (walking distance on the treadmill test >200 m) & $1(7.1 \%)$ & $4(28.6 \%)$ & $3(25 \%)$ & $4(28.6 \%)$ \\
\hline Symptoms of claudication (walking distance on the treadmill test $<200 \mathrm{~m}$ ) & $2(14.3 \%)$ & $2(14.3 \%)$ & $4(28.6 \%)$ & $2(14.3 \%)$ \\
\hline Type 1 diabetes mellitus & 3 & 3 & 3 & 3 \\
\hline Type 2 diabetes mellitus & 5 & 5 & 5 & 5 \\
\hline Reoperation & 0 & 0 & 1 & 2 \\
\hline Patients lost to follow-up & 0 & 1 & 1 & 0 \\
\hline Endovascular treatment for patients, $n$ & 31 & 30 & 29 & 29 \\
\hline Symptoms of claudication (walking distance on the treadmill test $>200 \mathrm{~m}$ ) & $2(6.5 \%)$ & $2(6.5 \%)$ & $1(3.4 \%)$ & $1(3.4 \%)$ \\
\hline Symptoms of claudication (walking distance on the treadmill test $<200 \mathrm{~m}$ ) & 0 & $2(6.5 \%)$ & $1(3.4 \%)$ & $1(3.4 \%)$ \\
\hline Type 1 diabetes mellitus & 3 & 3 & 3 & 3 \\
\hline Type 2 diabetes mellitus & 5 & 5 & 5 & 5 \\
\hline Endovascular re-intervention & 0 & 0 & 0 & 0 \\
\hline Patients lost to follow-up & 0 & 1 & 1 & 0 \\
\hline Claudication (walking distance on the treadmill test >200 m) Dacron vs. endovascular & 0.525 & 0.378 & 0.085 & 0.033 \\
\hline Claudication (walking distance on the treadmill test >200 m) GSV conduit vs. endovascular & 0.568 & 0.129 & 0.178 & 0.04 \\
\hline Claudication (walking distance on the treadmill test $<200 \mathrm{~m}$ ) Dacron vs. endovascular & 0.05 & 0.08 & 0.747 & 0.526 \\
\hline Claudication (walking distance on the treadmill test $<200 \mathrm{~m}$ ) GSV conduit vs. endovascular treatment & 0.169 & 0.799 & 0.05 & 0.046 \\
\hline
\end{tabular}

started to experience pain in the lower limbs was over $200 \mathrm{~m}$ in $12.8 \%$ one year after the surgery and the number of them was increased to $23.1 \%$ after four years.

A year after, $14.9 \%$ of patients had a maximum painfree walking distance on the treadmill test $<200 \mathrm{~m}$, and yet their number decreased in the following years (Table 1). There was significantly fewer patients with claudication symptoms in the group of endovascular treatment $(n=31$, $P=0.033$ ) who did the same test at the end of the fourth year. There was also statistically smaller number of patients who had claudication symptoms on the treadmill test $<200 \mathrm{~m}$ in the endovascular treatment group after the first year. When the treadmill test results for the four-year period were compared between the GSV conduit and endovascular treatment groups, the patients of the latter exhibited lesser claudication symptoms on the treadmill test $>200 \mathrm{~m}$, $P=0.04$, and $<200 \mathrm{~m}, \mathrm{P}=0.046$.
The comparison of CIMT mean values based on sex and diabetes mellitus type revealed no significant intragroup or intergroup differences over 4 years (Table 2). Patients with type 2 diabetes mellitus after endovascular treatment had some reduction in CIMT, albeit insignificant.

Comparing the walking distance on the treadmill test, it was obvious the large number of patients with Dacron graft for whom the claudication distance was $>200 \mathrm{~m}$ after which they started to experience pain in the lower limbs in four years after (Fig. 2). The patients of this group were more likely to have claudication distance of $<200 \mathrm{~m}$ after a year of treatment. When GSV conduit was used, the claudication symptoms were more common in walking distance of $>200 \mathrm{~m}$ in two years after. The results of MICT showed significantly better outcomes after endovascular treatment than classical bypass. Generally, the patients did not demonstrate lower incidence of claudication symptoms. 


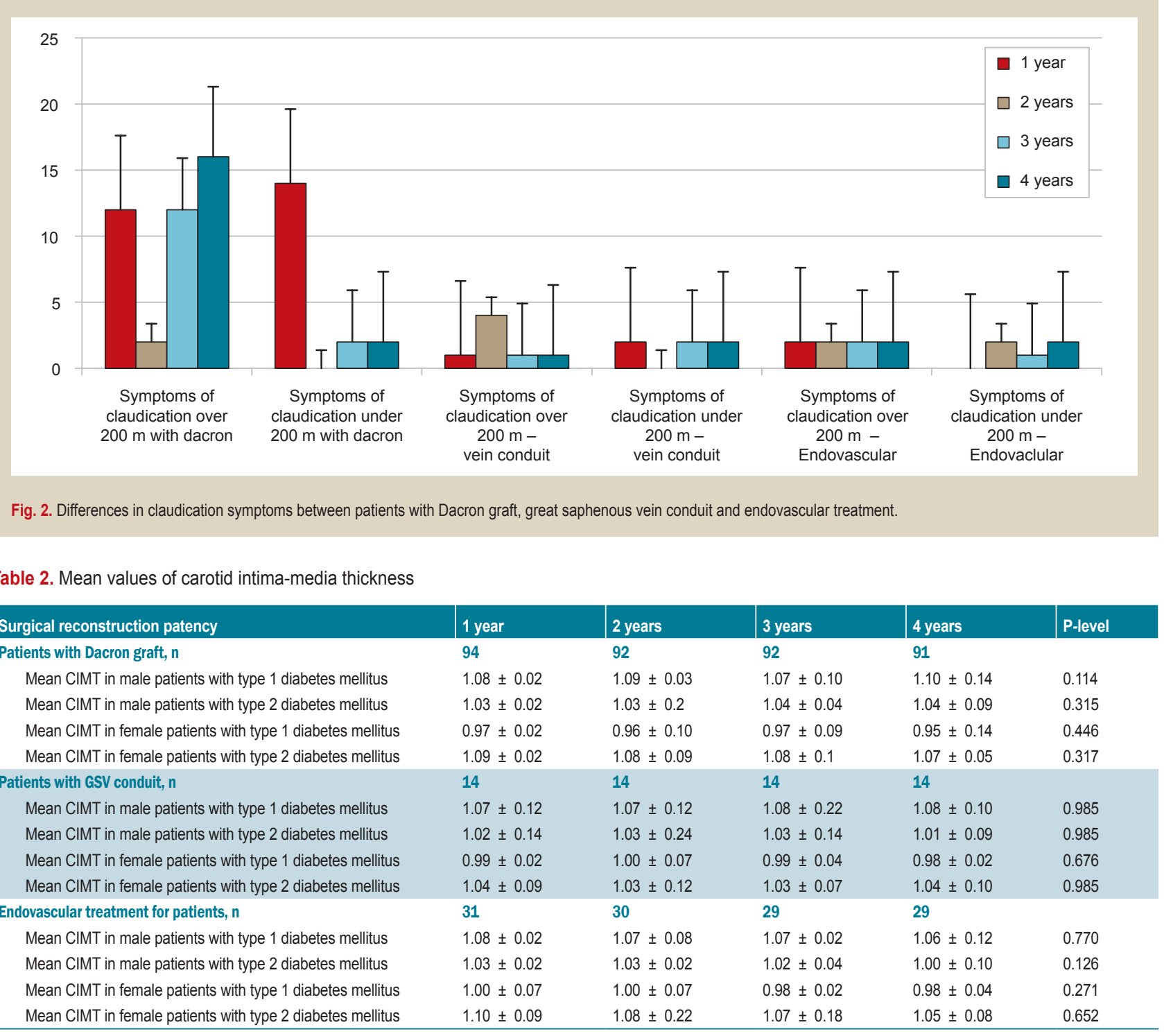

\section{Discussion}

Although surgical indications for revascularization have been expanding, and modern hybrid methods have significantly slowed down the development of conventional therapy, the objectives of many studies have been aimed at optimizing and improving different variations of vascular rehabilitation medicamentous therapy in combination with appropriate physical exercise. Physical activity is important as a crucial element of primary surgical conservative treatment and secondary prevention of peripheral artery disease in various stenotic segments and occlusions as well as subsequent cardio-cerebral-vascular disease, representing the primary possibility to reach treatment goals according to the criteria [14]. Endovascular treatment of stenotic or occlusive iliac segments including critical stenosis of the iliac segment (TASC IIA and B) followed by training by means of long-term exercise loaded at a moderate intensity with short resting intervals, has represented safe and substantiated successful treatment and primary bypass patency within 4 years. The approach has been proven to be especially effective at an average age of 52.7 for male and 54.5 for female population. Moreover, the authors underlined the effects of aging and multiple comorbidities in patients after endovascular procedures on the use of exercise training of moderate intensity, leading to the necessity of a personalized exercise-based vascular rehabilitation (running, stationary bicycle, anaerobic exercises) [15-17].

There has been much discussion and academic debate on the subject of vascular rehabilitation modality optimization for primary bypass patency or endovascular treatment. The exercise intensity depends on comorbidities and overall cardiovascular state of patients with cardiovascular disease and cardiovascular risk factors in terms of load and duration of physical activity (low, moderate or high intensity) as well as in patients who have already undergone the treatment. Many mechanism of different training intensity efficacy in reversing the specific symptoms in patients with confirmed critical stenosis of the iliac segment and peripheral arteries, manifested by intermittent claudication due to degenerative process or non-compensating collateral hemodynamics, and multiple risk factors after any type of procedure on the iliac segment (artery bypass grafting or endovascular) are not well understood [9,18-20]. Numerous substantive 
health benefits of cardiovascular postoperative rehabilitation exercise have been demonstrated. It was evidenced by improvements in comorbidities, especially in patients with risk factors, heart diseases and reduced left ventricular ejection fraction (EF) [21-24]. While the benefits for successful primary bypass patency, prevention of neointimal hyperplasia in Dacron material after surgical aorto-femoral and femoro-popliteal bypass treatment is still uncertain. The fact is that autologous vein graft bypass surgery is limited by a lack of good-quality autologous vein or significant stenosis defined as the luminal vessel diameter reduction of over $75 \%$ (TASC II A and B). Meanwhile, endovascular therapy for critical stenosis of the iliac segment (PTA and self-expendable stent, Dacron graft or stent implantation) is possible. MICT effects on revascularization with both primary bypass and endovascular intervention, as well as on the peripheral arteries and cardiovascular system (mostly on cardiac autonomic nervous system) are numerous and in synergy with medicamentous treatment, antithrombotic prophylaxis (Acetylsalicylic acid, Clopidogrel or Rivaroxaban) and statins. All this collectively forms an integral part of successful optimization of surgical and endovascular treatment along with a concept of dietary modification and risk factors reduction [25-30].

MICT loaded at a low intensity with short resting intervals until the onset of claudication pain have been found to be associated with improvements in anti-oxidant responses reducing oxidative stress. Therefore, it has been suggested that such training can help to prevent oxidative stress, atherosclerotic arterial wall remodeling and atheromatosis of arterial intima as well as to decrease carotid intima-media thickening and an incidence of cardio-cerebral vascular events with the benefit of primary bypass patency and endovascular or vascular interventions. It is also important to realize the significance of exercise benefits influence not only on primary bypass patency and vascular interventions, but also on systemic and peripheral circulation of other vital systems in terms of apparent direct protection in response to increases in perfusion pressure and improvements in distal circulation of limb arteries [31-33]. Benefits of MICT with short resting intervals are probably in direct correlation with arterial remodeling and hemodynamic improvement related to better global antioxidant status, as well as a protective support for cardio-cerebral atherosclerosis prevention and CIMT reduction. Beneficial effects include intima media of distal large arteries protection and potential reduction of neointimal hyperplasia development in various bypass conduits such as veins and prosthetic grafts (Dacron and venous material), and primary endovascular bypass patency using self-expendable stent/PTA in critical stenosis of iliac segment of over $75 \%$.

Taking into account a limitation of this pilot study including the small number of participants, a larger number of patients might be needed to detect statistically significant results. Nevertheless, continuous exposure to progressive risk factors (smoking, type 2 diabetes mellitus) and a considerable role of lifestyle influence require a key support that could be provided by continuation of the possible vascular treatment [34-37]. Vascular tone and arterial wall remodeling was revealed in patients after training as evidenced by significant changes in different arterial segments, especially in upper and lower extremity peripheral arteries and in the carotid basin. Obser- vational studies of Laughlin [38] and Tinken [39] have shown the complimentary nature of adaptations in the carotid basin arteries, and upper and lower extremity peripheral artery function and structure in response to 8 weeks' lower limb training. The initial increase in upper and lower limb conduit artery function in response to lower limb exercise training was followed by an increase in vascular structure in both vessels. Functional adaptations began to return to near baseline values, structural adaptations began to increase significantly across the 8-week exercise-training programme resulting in a better arterial remodeling, improving collateral compensation in atherosclerosis. While other authors (Van Duijnhoven [40] and Thijssen [41]) have shown in their studies on MICT that the artery wall adaptive changes in response to simulation training effects of running and stationary bicycle were to decrease a conduit artery wall thickness in comparison to carotid arteries with insignificant CIMT reduction in diabetic patients [42]. Hodis in a study [43] gave insights into the absolute CIMT as a reliable independent predictor of cardiovascular events. Even though endovascular treatment for stenosis of iliac segment seems to be superior to surgical treatment, clinical studies provide limited evidence with regard to various bypass patency or endovascular intervention for critical stenosis. Certainly, optimal training intensity could have a positive effect on primary bypass patency or endovascular interventions without putting patients at a risk of additional cardiovascular and respiratory complications, which are potential during physical activity in terms of load, further facilitating better medicamentous treatment [12]. High-intensity interval training in cardiovascular patients and patients with central obesity demonstrated positive effect on insulin sensitivity, body weight and reduced systolic and diastolic blood pressure. Physical training 3 times a week with an adequate lifestyle modification can increase aerobic capacity and improve everyday activities in patients. Moreover, treatments for peripheral arterial disease ranging from conservative measures, such as management of cardiovascular risk factors with medicamentous therapy (antiplatelets, statins) and exercise regimens, to interventional therapies, including surgical and endovascular arterial reconstruction can be directly improved with slowing down the progression of CIMT in both diabetic and non-diabetic patients [12, 43-48]. In sum, reduced progression or net regression of CIMT was attainable in patients with type 2 diabetes mellitus who underwent endovascular or classic surgical treatment [38-49]. Individuals with type 2 diabetes after endovascular or bypass treatment can greatly improve general well-being with positive cardio-protective effects by following a nutritious meal plan and exercise program, implementing necessary self-care behaviors, and taking oral medications postoperatively as well as reducing risk factors. High intensity trainings were associated with a reduction in ischemic and hemorrhagic stroke incidence and potential improvements in physical performance in $31 \%$ of patients with small number of comorbidities [49]. MICT with short resting intervals and high load can improve everyday activity of patients and their overall well-being. However, it does not help to promote the therapeutic and rehabilitation goals because it can not both improve physical performance in patients and influence the prevention or progression of hypertension symptomatology, dyslipidemia, brain stroke and type 2 diabetes mellitus. Therefore, intensive and continuous training of moderate intensity with short resting 
intervals and high load mitigates the critical ischemia effects in iliac segment stenosis of over $75 \%$ (TASC II A and B) or chronic ischemia of distal femoro-popliteal segment after endovascular or bypass procedure, thus resulting in a higher level of therapeutic potential of surgical and endovascular treatment $[50,51]$.

\section{Conclusions}

1. There are clear benefits associated with adequate application of moderate-intensity continuous training of slightly increased load with short resting intervals in influencing primary graft patency in patients with synthetic or endovascular revascularization of iliac segment critical stenosis (TASC II A and B) and venous bypass graft of the femoro-popliteal segment.

2. There are significant benefits from application of moderate-intensity continuous training for primary graft patency after ilio-femoral segment bypass surgery in comparison to femoro-popliteal segment, and non-statistically significant decrease in carotid intima-media thickness in some patients.

3. Medium-intensity continuous training significantly impacts bypass patency and endovascular procedure in patients after any type of revascularization procedure on the iliac segment (artery bypass grafting or endovascular) according to TASC II A and B criteria and improves the quality of life in combination with a programme of risk factors reduction, diet and lifestyle modification.

\section{Acknowledgements}

We are grateful to Mr. Mensur Vrcić MD, PhD, Ratko Pavlović MD, $\mathrm{PhD}$ (Sport University of Sarajevo and East Sarajevo, BIH) for vascular rehabilitation support and realization of this important study, and Iryna Skrypchenko PhD (Dnipropetrovsk State University of Internal Affairs, Department of Physical Education, Ukraine) for improvement of postoperative classical bypass and endovascular rehabilitation therapy. We would also like to thank all the treated patients for their voluntary participation and outstanding cooperation in the study.

Conflicts of interest: authors have no conflict of interest to declare. Конфмікт інтересів: віАсутній.

Надійшла Ао редакції / Received: 12.09.2019

Після Аоопрацювання / Revised: 01.11.2019

Прийнято Ао Аруку / Accepted: 07.09.2020

Information about authors:

Solaković Sid, MD, Clinic for Cardiovascular Surgery and Department for Vascular Surgery, University Clinical Center of Sarajevo; Special Hospital dr. Solakovic, Department for Vascular Surgery and Vascular Rehabilitation; The International University of Gorazde (IUG), Medical Faculty, BIH.

ORCID ID: 0000-0001-6092-1985

Jogončić Anes, MD, Medical Faculty, Department of Forensic

Medicine, University of Sarajevo, BIH.

ORCID ID: 0000-0001-6926-0079

Pavlović Ratko, Faculty of Physical Education and Sport, University of Sarajevo, BIH.

ORCID ID: 0000-0002-4007-4595

Vrcić Mensur, Faculty of Sport and Physical Education, University of Sarajevo, BIH.

ORCID ID: 0000-0002-8331-9062

Čović Nedim, Faculty of Sport and Physical Education, University of Sarajevo, BIH.

ORCID ID: 0000-0002-1539-866X
Solaković Emir, MD, Department for Vascular Surgery and Vascular Rehabilitation, Special Hospital dr.Solakovic, BIH. ORCID ID: 0000-0001-5893-3522

Skrypchenko I. T., Department of Physical Education,

Dnipropetrovsk State University of Internal Affairs, Dnipro, Ukraine.

ORCID ID: 0000-0001-5895-3099

Čaušević Denis, Faculty of Sport and Physical Education,

University of Sarajevo, BIH.

ORCID ID: 0000-0003-2400-9352

Dorofieieva O. Ye., MD, PhD, DSc, Associate Professor, Head of the Department of Physical Rehabilitation and Sport Medicine, 0. O. Bogomolets National Medical University, Kyiv, Ukraine.

ORCID ID: 0000-0002-2028-6064

Yarymbash K. S., PhD, Associate Professor of the Department of Physical Rehabilitation and Sport Medicine, 0. O. Bogomolets National Medical University, Kyiv, Ukraine.

ORCID ID: 0000-0003-4694-291X

\section{Відомості про авторів:}

Солакович Сід, кмініка серцево-судинної хірургії та відАілення судинної хірургії Кмінічного центру університету Сараєво; Спеціальна лікарня Аоктора Солаковича, відділення судинної хірургії та судинної реабімітації; Міжнародний університет ГоражАе (IUG), меАичний факультет, Боснія і Герцеговина. Йогончич Анеш, каф. судової медицини, меАичний факультет, Університет Сараєво, Боснія і Герцеговина.

Павлович Ратко, факультет фізичного виховання і спорту, Університет Східного Сараєво, Боснія і Герцеговина. Врчич Менсур, факультет спорту та фізичного виховання, Університет Сараєво, Боснія і Герцеговина.

Чович Недім, факультет спорту та фізичного виховання, Університет Сараєво, Боснія і Герцеговина.

Солакович Емір, відвілення судинної хірургії та судинної реабімітації, Спеціальна мікарня доктора Солаковича, Боснія і Герцеговина.

Скрипченко І. Т., каф. фізичного виховання, Аніпропетровський державний університет внутрішніх справ, м. Аніпро, Україна.

Чаушевич Аенис, факультет спорту та фізичного виховання, Університет Сараєво, Боснія і Герцеговина.

Аорофєєва О. Є., А-р меА. наук, Аоцент, зав. каф. фізичної реабілітації та спортивної медицини, Національний медичний університет імені О. О. Богомольця, м. Київ, Україна. Яримбаш К. С., канА. пеА. наук, Аоцент каф. фізичної реабілітації та спортивної медицини, Національний медичний університет імені О. О. Богомольця, м. Київ, Україна.

\section{Сведения об авторах:}

Солакович СиА, кииника серАечно-сосудистой хирургии и отАеление сосуАистой хирургии, Клинический центр Университета Сараево; Специальная больница доктора Солаковича, отАеление сосудистой хирургии и сосудистой реабилитации; МежАународный университет ГоражАе (IUG), мелицинский факультет, Босния и Герцеговина.

Йогончич Анес, медицинский факультет, каф. судебной медицины, Сараевский университет, Босния и Герцеговина. Павлович Ратко, факультет физического воспитания и спорта, Университет Восточного Сараево, Босния и Герцеговина.

Врчич Менсур, факультет спорта и физического воспитания, Сараевский университет, Босния и Герцеговина.

Чович Недим, факультет спорта и физического воспитания, Университет Сараево, Босния и Герцеговина.

Солакович Эмир, отАеление сосудистой хирургии и сосудистой реабилитации, Специальная больница Аоктора Солакович, Босния и Герцеговина.

Скрипченко И. Т., каф. физического воспитания,

Анепропетровский государственный университет внутренних Аел, г. Анипро, Украина.

Чаушевич Аенис, факультет спорта и физической культуры, Сараевский университет, Босния и Герцеговина.

Аорофеева Е. Е., А-р меА. наук, Аоцент, зав. каф. физической реабилитации и спортивной медицины, Национальный медицинский университет имени А. А. Богомольца, г. Киев, Украина.

Ярымбаш К. С., канд. пеА. наук, Аоцент каф. физической реабилитации и спортивной меАицины, Национальный медицинский университет имени А. А. Богомольца, г. Киев, Украина. 
References

[1] Robeer, G. G., Brandsma, J. W., van den Heuvel, S. P., Smit, B., Oostendorp, R. A. B., \& Wittens, C. H. A. (1998). Exercise therapy for intermittent claudication: A review of the quality of randomised clinical trials and evaluation of predictive factors. European Journal of Vascular and Endovascular Surgery, 15(1), 36-43. https://doi.org/10.1016/ s1078-5884(98)80070-1

[2] Setacci, C., de Donato, G., Teraa, M., Moll, F. L., Ricco, J. -B., Becker, F., Robert-Ebadi, H., Cao, P., Eckstein, H. H., De Rango, P., Diehm, N., Schmidli, J., Dick, F., Davies, A. H., Lepäntalo, M., \& Apelqvist, J. (2011). Chapter IV: Treatment of Critical Limb Ischaemia. European Journal of Vascular and Endovascular Surgery, 42(Suppl. 2), S43-S59. https://doi.org/10.1016/s1078-5884(11)60014-2

[3] Bisdas, T., Borowski, M., Torsello, G., Adili, F., Balzer, K., Betz, T., Billing, A., Böckler, D., Brixner, D., Debus, S. E., Donas, K. P., Eckstein, H. -H., Florek, H. -J., Gkremoutis, A., Grundmann, R., Hupp, T. Keck, T., Gerß, J., Klonek, W., ... Zimmermann, A. (2015). Current practice of first-line treatment strategies in patients with critical limb ischemia. Journal of Vascular Surgery, 62(4), 965-973.e3. https://doi. org/10.1016/j.jvs.2015.04.441

[4] Timaran, C. H., Prault, T. L., Stevens, S. L., Freeman, M. B., \& Goldman, M. H. (2003). Iliac artery stenting versus surgical reconstruction for TASC (transatlantic inter-society consensus) type B and type C iliac lesions. Journal of Vascular Surgery, 38(2), 272-278. https://doi. org/10.1016/s0741-5214(03)00411-7

[5] Meijer, W. T., Hoes, A. W., Rutgers, D., Bots, M. L., Hofman, A., \& Grobbee, D. E. (1998). Peripheral Arterial Disease in the Elderly. Arteriosclerosis, Thrombosis, and Vascular Biology, 18(2), 185-192. https://doi.org/10.1161/01.atv.18.2.185

[6] Selvin, E., \& Erlinger, T. P. (2004). Prevalence of and Risk Factors for Peripheral Arterial Disease in the United States. Circulation, 110(6), 738-743. https://doi.org/10.1161/01.cir.0000137913.26087.f0

[7] Støa, E. M., Meling, S., Nyhus, L. -K., Glenn Strømstad, Mangerud, K. M., Helgerud, J., Bratland-Sanda, S., \& Støren, Ø. (2017). High-intensity aerobic interval training improves aerobic fitness and $\mathrm{HbA} 1 \mathrm{c}$ among persons diagnosed with type 2 diabetes. European Journal of Applied Physiology, 117(3), 455-467. https://doi.org/10.1007/ s00421-017-3540-1

[8] Gaeini, A., Satarifard, S., \& Heidary, A. (2014). Comparing the effect of eight weeks of high-intensity interval training and moderate-intensity continuous training on physiological variables of exercise stress test in cardiac patient after coronary artery bypass graft. Journal of Isfahan Medical School, 31, 2171-2181.

[9] Cachovan, M. (1999). Methods and results of controlled walking training in patients with peripheral arterial occlusive disease. Zeitschrift fur arztliche Fortbildung und Qualitatssicherung, 93(9), 626-632.

[10] Wind, J., \& Koelemay, M. J. W. (2007). Exercise Therapy and the Additional Effect of Supervision on Exercise Therapy in Patients with Intermittent Claudication. Systematic Review of Randomised Controlled Trials. European Journal of Vascular and Endovascular Surgery, 34(1), 1-9. https://doi.org/10.1016/j.ejvs.2006.12.030

[11] Brandsma, J. W., Robeer, B. G., van den Heuvel, S., Smit, B., Wittens, C. H., \& Oostendorp, R. A. (1998). The Effect of Exercises on Walking Distance of Patients With Intermittent Claudication: A Study of Randomized Clinical Trials. Physical Therapy, 78(3), 278-286. https:/l doi.org/10.1093/ptj/78.3.278

[12] Criqui, M. H., Denenberg, J. O., Langer, R. D., \& Fronek, A. (1997). The Epidemiology of Peripheral Arterial Disease: Importance of Identifying the Population at Risk. Vascular Medicine, 2(3), 221-226. https://doi. org/10.1177/1358863×9700200310

[13] Fowkes, F. G. R., Housley, E., Cawood, E. H. H., Macintyre, C. C. A. Ruckley, C. V., \& Prescott, R. J. (1991). Edinburgh Artery Study: Prevalence of Asymptomatic and Symptomatic Peripheral Arterial Disease in the General Population. International Journal of Epidemiology, 20(2), 384-392. https://doi.org/10.1093/ije/20.2.384

[14] Parmenter, B. J., Dieberg, G., Phipps, G., \& Smart, N. A. (2015). Exercise training for health-related quality of life in peripheral artery disease: A systematic review and meta-analysis. Vascular Medicine, 20(1), 30-40. https://doi.org/10.1177/1358863x14559092

[15] Kudo, T., Chandra, F. A., \& Ahn, S. S. (2005). Long-term outcomes and predictors of iliac angioplasty with selective stenting. Journal of Vascular Surgery, 42(3), 466.e1-466.e13. https://doi.org/10.1016/j. jvs.2005.05.002

[16] Reese, C., Nechwatal, R., \& Farin, E. (2019). Welche Erwartungen haben Rehabilitanden an eine telemedizinische kardiologische Reha-Nachsorge? Ergebnisse aus Interviews mit Rehabilitanden. Zeitschrift fur Evidenz, Fortbildung und Qualitat im Gesundheitswesen, 143, 43-48. https://doi.org/10.1016/j.zefq.2019.04.003

[17] Earnest, C. (2009). The role of exercise interval training in treating cardiovascular disease risk factors. Current Cardiovascular Risk Reports, 3(4), Article 296. https://doi.org/10.1007/s12170-009-0045-4
[18] Fleg, J. L., Cooper, L. S., Borlaug, B. A., Haykowsky, M. J., Kraus, W. E., Levine, B. D., Pfeffer, M. A., Piña, I. L., Poole, D. C., Reeves, G. R. Whellan, D. J., \& Kitzman, D. W. (2015). Exercise Training as Therapy for Heart Failure. Circulation: Heart Failure, 8(1), 209-220. https://doi. org/10.1161/circheartfailure. 113.001420

[19] Wisløff, U., Støylen, A., Loennechen, J. P., Bruvold, M., Rognmo, Ø. Haram, P. M., Tjønna, A. E., Helgerud, J., Slørdahl, S. A., Lee, S. J. Videm, V., Bye, A., Smith, G. L., Najjar, S. M., Ellingsen, Ø., \& Skjærpe, T. (2007). Superior Cardiovascular Effect of Aerobic Interval Training Versus Moderate Continuous Training in Heart Failure Patients. Circulation, 115(24), 3086-3094. https://doi.org/10.1161/circulationaha.106.675041

[20] Hussain, S. R., Macaluso, A., \& Pearson, S. J. (2016). High-Intensity Interval Training Versus Moderate-Intensity Continuous Training in the Prevention/Management of Cardiovascular Disease. Cardiology in Review, 24(6), 273-281. https://doi.org/10.1097/ crd.0000000000000124

[21] Specchia, G., De Servi, S., Scire', A., Assandri, J., Berzuini, C. Angoli, L., La Rovere, M. T., \& Cobelli, F. (1996). Interaction Between Exercise Training and Ejection Fraction in Predicting Prognosis Afte a First Myocardial Infarction. Circulation, 94(5), 978-982. https://doi. org/10.1161/01.cir.94.5.978

[22] Haddadzadeh, M. H., Maiya, A. G., Padmakumar, R., Shad, B., \& Mirbolouk, F. (2011). Effect of exercise-based cardiac rehabilitation on ejection fraction in coronary artery disease patients: a randomized controlled trial. Heart Views, 12(2), 51-57. https://doi.org/10.4103/1995705X.86013

[23] Ehsani, A. A., Biello, D. R., Schultz, J., Sobel, B. E., \& Holloszy, J. O. (1986). Improvement of left ventricular contractile function by exercise training in patients with coronary artery disease. Circulation, 74(2), 350-358. https://doi.org/10.1161/01.cir.74.2.350

[24] Keteyian, S. J. (2013). Exercise Training in Patients With Heart Failure and Preserved Ejection Fraction. Journal of the American College of Cardiology, 62(7), 593-594. https://doi.org/10.1016/j.jacc.2013.01.098

[25] Rankin, A. J., Rankin, A. C., Macintyre, P., \& Hillis, W. S. (2011). Walk or run? is high-intensity exercise more effective than moderate-intensity exercise at reducing cardiovascular risk? Scottish Medical Journal, 57(2), 99-102. https://doi.org/10.1258/smj.2011.011284

[26] Nechwatal, R. M., Duck, C. \& Gruber, G. (2002). Körperliches Training als Intervall- oder kontinuierliches Training bei chronischer Herzinsuffizienz zur Verbesserung der funktionellen Leistungskapazität, Hämodynamik und Lebensqualität - eine kontrollierte Studie. Zeitschrift Für Kardiologie, 91(4), 328-337. https://doi.org/10.1007/s003920200034

[27] Heran, B. S., Chen, J. M., Ebrahim, S., Moxham, T., Oldridge, N. Rees, K., Thompson, D. R., \& Taylor, R. S. (2011). Exercise-based cardiac rehabilitation for coronary heart disease. Cochrane Database of Systematic Reviews, (7), Article CD001800. https://doi. org/10.1002/14651858.cd001800.pub2

[28] Goldsmith, R. L., Bloomfield, D. M., \& Rosenwinkel, E. T. (2000). Exercise and autonomic function. Coronary Artery Disease, 11(2), 129-135. https://doi.org/10.1097/00019501-200003000-00007

[29] Piepoli, M. F., Guazzi, M., Boriani, G., Cicoira, M., Corrà, U., Libera, L. D., Emdin, M., Mele, D., Passino, C., Vescovo, G., Vigorito, C., Villani, G. Q., \& Agostoni, P. (2010). Exercise intolerance in chronic heart failure: mechanisms and therapies. Part I. European Journal of Cardiovascular Prevention \& Rehabilitation, 17(6), 637-642. https://doi. org/10.1097/hir.0b013e3283361dc5

[30] Oldridge, N. B. (1988). Cardiac rehabilitation after myocardial infarction Combined experience of randomized clinical trials. JAMA: The Journal of the American Medical Association, 260(7), 945-950. https://doi. org/10.1001/jama.260.7.945

[31] Willie, C. K., Tzeng, Y. -C., Fisher, J. A., \& Ainslie, P. N. (2014). Integrative regulation of human brain blood flow. The Journal of Physiology, 592(5), 841-859. https://doi.org/10.1113/jphysiol.2013.268953

[32] Ogoh, S., \& Ainslie, P. N. (2009). Cerebral blood flow during exercise: mechanisms of regulation. Journal of Applied Physiology, 107(5), 13701380. https://doi.org/10.1152/japplphysiol.00573.2009

33] Gibala, M. J., \& McGee, S. L. (2008). Metabolic Adaptations to Shortterm High-Intensity Interval Training. Exercise and Sport Sciences Reviews, 36(2), 58-63. https://doi.org/10.1097/jes.0b013e318168ec1f

[34] Gomez-Cabrera, M. -C., Domenech, E., \& Viña, J. (2008). Moderate exercise is an antioxidant: Upregulation of antioxidant genes by training. Free Radical Biology and Medicine, 44(2), 126-131. https://doi. org/10.1016/j.freeradbiomed.2007.02.001

[35] Ait-Oufella, H., Taleb, S., Mallat, Z., \& Tedgui, A. (2011). Recent Advances on the Role of Cytokines in Atherosclerosis. Arteriosclerosis, Thrombosis, and Vascular Biology, 31(5), 969-979. https://doi. org/10.1161/atvbaha.110.207415

[36] Ribeiro, F., Alves, A. J., Duarte, J. A., \& Oliveira, J. (2010). Is exercise training an effective therapy targeting endothelial dysfunction and vascular wall inflammation? International Journal of Cardiology, 141(3) 214-221. https://doi.org/10.1016/j.jijcard.2009.09.548 
[37] Althouse, A. D., Abbott, J. D., Forker, A. D., Bertolet, M., Barinas-Mitchell, E., Thurston, R. C., Mulukutla, S., Aboyans, V., \& Brooks, M. M. (2014). Risk Factors for Incident Peripheral Arterial Disease in Type 2 Diabetes: Results From the Bypass Angioplasty Revascularization Investigation in Type 2 Diabetes (BARI 2D) Trial. Diabetes Care, 37(5), 1346-1352. https://doi.org/10.2337/dc13-2303

[38] Laughlin, M. H. (1995). Endothelium-mediated control of coronary vascular tone after chronic exercise training. Medicine \& Science in Sports \& Exercise, 27(8), 1135-1144. https://doi.org/10.1249/00005768199508000-00006

[39] Tinken, T. M., Thijssen, D. H. J., Black, M. A., Cable, N. T., \& Green, D. J. (2008). Time course of change in vasodilator function and capacity in response to exercise training in humans. The Journal of Physiology, 586(20), 5003-5012. https://doi.org/10.1113/jphysiol.2008.158014

[40] van Duijnhoven, N. T. L., Green, D. J., Felsenberg, D., Belavý, D. L., Hopman, M. T. E., \& Thijssen, D. H. J. (2010). Impact of Bed Rest on Conduit Artery Remodeling. Hypertension, 56(2), 240-246. https://doi. org/10.1161/hypertensionaha.110.152868

[41] Thijssen, D. H. J., Dawson, E. A., van den Munckhof, I. C. L., Tinken, T. M., den Drijver, E., Hopkins, N., Cable, N. T., \& Green, D. J. (2011). Exercise-mediated changes in conduit artery wall thickness in humans: role of shear stress. American Journal of Physiology-Heart and Circulatory Physiology, 301(1), H241-H246. https://doi.org/10.1152/ ajpheart.00170.2011

[42] Maiorana, A., O'Driscoll, G., Cheetham, C., Collis, J., Goodman, C., Rankin, S., Taylor, R., \& Green, D. (2000). Combined aerobic and resistance exercise training improves functional capacity and strength in CHF. Journal of Applied Physiology, 88(5), 1565-1570. https://doi. org/10.1152/jappl.2000.88.5.1565

[43] Hodis, H. N., Mack, W. J., LaBree, L., Selzer, R. H., Liu, C. R., Liu, C. H., \& Azen, S. P. (1998). The Role of Carotid Arterial Intima-Media Thickness in Predicting Clinical Coronary Events. Annals of Internal Medicine, 128(4), 262-269. https://doi.org/10.7326/0003-4819-128-4199802150-00002

[44] Colberg, S. R., Sigal, R. J., Fernhall, B., Regensteiner, J. G., Blissmer, B. J., Rubin, R. R., Chasan-Taber, L., Albright, A. L., Braun, B., American College of Sports Medicine, \& American Diabetes Association. (2010). Exercise and Type 2 Diabetes: The American College of Sports Medicine and the American Diabetes Association: joint position statement. Diabetes Care, 33(12), e147-e167. https://doi. org/10.2337/dc10-9990

[45] Kim, S. H., Lee, S. J., Kang, E. S., Kang, S., Hur, K. Y., Lee, H. J., Ahn, C. W., Cha, B. S., Yoo, J. S., \& Lee, H. C. (2006). Effects of lifestyle modification on metabolic parameters and carotid intima-media thickness in patients with type 2 diabetes mellitus. Metabolism, 55(8), 1053-1059. https://doi.org/10.1016/i.metabol.2006.03.017

[46] Niebauer, J., Hambrecht, R., Velich, T., Hauer, K., Marburger, C., Kälberer, B., Weiss, C., von Hodenberg, E., Schlierf, G., Schuler, G. Zimmermann, R., \& Kübler, W. (1997). Attenuated Progression of Coronary Artery Disease After 6 Years of Multifactorial Risk Intervention. Circulation, 96(8), 2534-2541. https://doi.org/10.1161/01.cir.96.8.2534

[47] Byrkjeland, R., Stensæth, K.-H., Anderssen, S., Njerve, I. U. Arnesen, H., Seljeflot, I., \& Solheim, S. (2016). Effects of exercise training on carotid intima-media thickness in patients with type 2 diabetes and coronary artery disease. Influence of carotid plaques. Cardiovascular Diabetology, 15, Article 13. https://doi.org/10.1186/ s12933-016-0336-2

[48] Yokoyama, H., Katakami, N., \& Yamasaki, Y. (2006). Recent Advances of Intervention to Inhibit Progression of Carotid Intima-Media Thickness in Patients With Type 2 Diabetes Mellitus. Stroke, 37(9), 2420-2427. https://doi.org/10.1161/01.str.0000236632.58323.cd

[49] Lee, I. -M. Hennekens, C. H., Berger, K., Buring, J. E \& Manson, J. E. (1999). Exercise and Risk of Stroke in Male Physicians. Stroke, 30(1), 1-6. https://doi.org/10.1161/01.str.30.1.1

[50] Warburton, D. E., Nicol, C. W., \& Bredin, S. S. (2006). Health benefits of physical activity: the evidence. Canadian Medical Association Journal, 174(6), 801-809. https://doi.org/10.1503/cmaj.051351

[51] Wen, C. P., Wai, J. P. M., Tsai, M. K., Yang, Y. C., Cheng, T. Y. D. Lee, M. -C., Chan, H. T., Tsao, C. K., Tsai, S. P., \& Wu, X. (2011). Minimum amount of physical activity for reduced mortality and extended life expectancy: a prospective cohort study. Lancet, 378(9798), 1244-1253. https://doi.org/10.1016/S0140-6736(11)60749-6 